УДК 37.011

DOI:

Наталія Матвеєва, кандидат педагогічних наук, доцент кафедри педагогіки початкової освіти Прикарпатського національного університету імені Василя Стефаника

Надія П'ятка, студентка

Прикарпатського національного університету імені Василя Стефаника

\title{
ВНЕСОК О.Я. САВЧЕНКО У РОЗВИТОК ПОЧАТКОВОЇ ОСВІТИ
}

У статті проаналізовано науковий доробок О. Савченко та встановлено його значення у розвитку освітньої галузі в Украйні. Проведено порівняльний аналіз наукових праџь за чисельністю та тематичним спрямуванням з 1968-2015 рр., визначено наукову активність дослідниці у різних напрямах. Виокремлено актуальні проблеми, порушені авторкою; наголошено на практичному значенні ідей та поглядів О. Савченко.

Ключові слова: педагог; професійна підготовка; розвиток освіти; початкова освіта; наукова діяльність; педагогічна майстерність.

Рис. 3. Табл. 1. Літ. 7.

Nataliia Matveieva, Ph.D.(Pedagogy), Associate Professor of the Pedagogy of Primary Education Department, Vasyl Stefanyk Precarpathian National University

Nadiia Piatka, Student,

Vasyl Stefanyk Precarpathian National University

\section{SAVCHENKO'S CONTRIBUTION TO THE DEVELOPMENT OF PRIMARY EDUCATION}

The article considers the peculiarities of $O$. Savchenko's works and their significance in the formation of primary education. An important place in the development of primary education in Ukraine is occupied by her works, who studied various aspects of primary education. A significant number of works of the scientist proves her desire to help everyone in finding their own self, professional growth, improving the effectiveness of pedagogical action, achieving their own image in professional activities. A comparative analysis of scientific papers by number and thematic direction from 1968 to 2015, which indicates the scientific activity of the researcher in various fields. The most active period of the author's scientific work were 2001-2015. From 1968 to 1978 the number of works was 77 works, 1979-1989-96 works, from 1990-2000-158 works, 2001-2015-183 units. Since 2008, O. Savchenko has supervised 61 dissertation research. Based on the analysis, it was investigated that the problems of education development in our country are the number one issue in the activities of the researcher. The most significant developments of the 90 s, which are devoted to the problems of reforming the education sector during the first decade of Ukraine's independence, are highlighted. An excerpt from an interview "School principal. School World", where the scientist gives important instructions to young scientists. The analysis of O. Savchenko's scientific works shows the breadth of issues that the scientist tried to study, study and reveal in the light of modern requirements for the development of the educational sector of Ukraine. A wide range of issues covered in the scientific her works, allows successors to reveal the content, functions, features of the educational field and directs them in the appropriate direction of professional activity and self-development.

Keywords: professional training; education development; primary education; research activities; documents on education.

A ктуальність дослідження. На сучасному етапі розвитку освітньої галузі в Україні першочергового значення набуває ії модернізація, що передбачає трансформацію змісту, використання інноваційних технологій та використання передового педагогічного досвіду, упровадження нетрадиційних форм і методів навчання та виховання молоді, опору на науковий доробок учених, урахування запитів здобувачів освіти. Досягнення поставлених цілей щодо формування гармонійно розвинутої особистості вимагає розв'язання низки завдань учителямипрактиками й, зокрема, підвищення їх професійного рівня. На цьому наголошують основні нормативно-правові документи про освіту, а саме закони України "Про освіту", "Про дошкільну освіту”, “Про загальну середню освіту”, “Про вищу освіту”, Державний стандарт загальної середньої освіти, Концепція Нової Української школи. Остання, зокрема, зазначає, що виникла потреба формування низки компетентностей учителя, перегляду підходів до його професійної підготовки та підвищення кваліфікації тощо. Професійне зростання педагога має базуватися на вивченні досягнень науки та техніки, розширенні кругозору, поглибленні знань, 
розвитку ключових компетенцій, що уможливлює занурення у творчий доробок науковців, учителівноваторів, дослідників.

У контексті означеного чільне місце у розвитку початкової освіти в Україні посідає доробок відомого педагога Олександри Яківни Савченко, яка вивчала різноманітні їі аспекти. Рефреном через усю наукову спадщину О. Савченко проходить ідея про необхідність неперервної освіти учителя, його самовдосконалення та саморозвиток, що впливають на якість й ефективність формування особистості молодшого школяра. На міркування О. Савченко, учитель-практик зобов'язаний постійно розвиватись аж доти, доки не досягне найвищого щабля педагогічної майстерності. Чимала кількість праць вченої доводить, що вона глибоко переконана у власних думках та прагне допомогти кожному у пошуку власне себе, професійному зростанні, підвищенні ефективності педагогічної дії, досягненні власного іміджу у професійній діяльності.

Теоретико-методологічна основа дослідження. Аналіз актуалізованих джерел означеної проблеми свідчить про те, що попри особливе значення щодо розвитку педагогіки й, зокрема, початкової освіти, науковий доробок О. Савченко не $є$ повністю висвітленим дослідниками. Натомість актуальність ідей та поглядів вченої, затребуваність опублікованих підручників та чинних програм розглядали у своїх працях Л. Березівська, Ю. Блудова, Н. Руденко, Д. Соловйова, О. Топузов та інші.

Мета статті - розкрити багатогранну спадщину О. Савченко та визначити іiі місце у розвитку початкової освіти в Україні.

Виклад основного матеріалу. Олександра Яківна Савченко - відомий український педагог, доктор педагогічних наук, почесний працівник у галузі освіти, новатор у царині педагогіки початкової школи, віце-президент та академікзасновник Національної академії педагогічних наук України, головний науковий співробітник відділу початкової освіти Інституту педагогіки НАПН України та Лауреат Державної премії в галузі освіти. За грунтовний внесок у розвиток педагогічної науки та становлення освітньої галузі у нашій країні О. Савченко була нагороджена Орденом княгині Ольги I, II, III ступенів, Орденом князя Ярослава Мудрого V ступеня. Вчена торувала свій творчий шлях від учителя початкових класів до знаного академіка, охоплюючи різні вектори педагогічної, наукової, організаційно-управлінської діяльності. Осягнення всього внеску у розвиток освітньої галузі в Україні потребує глибокого вивчення багатогранних наукових пошуків О. Савченко, аналізу іiї значного історико-педагогічного доробку, що, своєю чергою, засвідчує глибинність, прогностичність, практичну зорієнтованість поглядів дослідниці [1].

Аналіз наукових праць О. Савченко показав широту питань, які намагалася вивчити, опрацювати та розкрити у світлі останніх вимог щодо розбудови освітньої галузі вчена. Слід зауважити, що наукова діяльність О. Савченко охоплює концептуальну та нормотворчу галузі супроводу загальної середньої освіти України. Основна ідея - підвищення якості надання освітніх послуг, розвиток галузі в державі та входження у європейський освітні простір, створення нової української школи (пошуки джерел мотивації навчання, виховання й розвитку особистості; формування базових умінь і навичок молодших школярів; дослідження змістового наповнення циклів предметів й міжпредметного змісту), підвищення кваліфікації учителів, перегляд традиційних підходів до педагогічного керівництва та управління закладами освіти [5]. Загальновідомо, що вчена є автором педагогічної системи формування пізнавальної самостійності молодших школярів. Праці О. Савченко вирізняються нетиповістю стилю, висвітленням нетрадиційних підходів до розв'язання проблем функціонування освітнього закладу, професійної діяльності педагогів тощо.

Особливе місце у науковому доробку О. Савченко посідає робота щодо підготовки низки нормативних документів про освіту, а саме: "Концепції державних стандартів загальної середньої освіти для 11 та 12-річних шкіл”; “Концепції 12-річної школи”; "Концепції початкової освіти”; “Державного стандарту початкової освіти”; “Державного стандарту загальної середньої освіти” тощо.

Такий напрям діяльності свідчить про особливу увагу О. Савченко до розвитку освіти в Україні, прагнення допомогти шляхом зміни керівних нормативних документів й положень щодо іiї реалізації з урахуванням можливостей, умов, вимог та запитів учасників освітнього процесу.

Як показало вивчення наукового доробку О. Савченко, її активна позиція, позитивізм, велика працездатність та любов до рідної держави, професії, спонукали до написання понад 700 праць, кожна 3 яких особливо цінна. Основними науковими роботами вченої уважаємо численні монографії (до прикладу, “Розвиток пізнавальної самостійності молодших школярів”), шкільні підручники (Читанка). Заслуговують на увагу й навчальні посібники для молодших школярів 


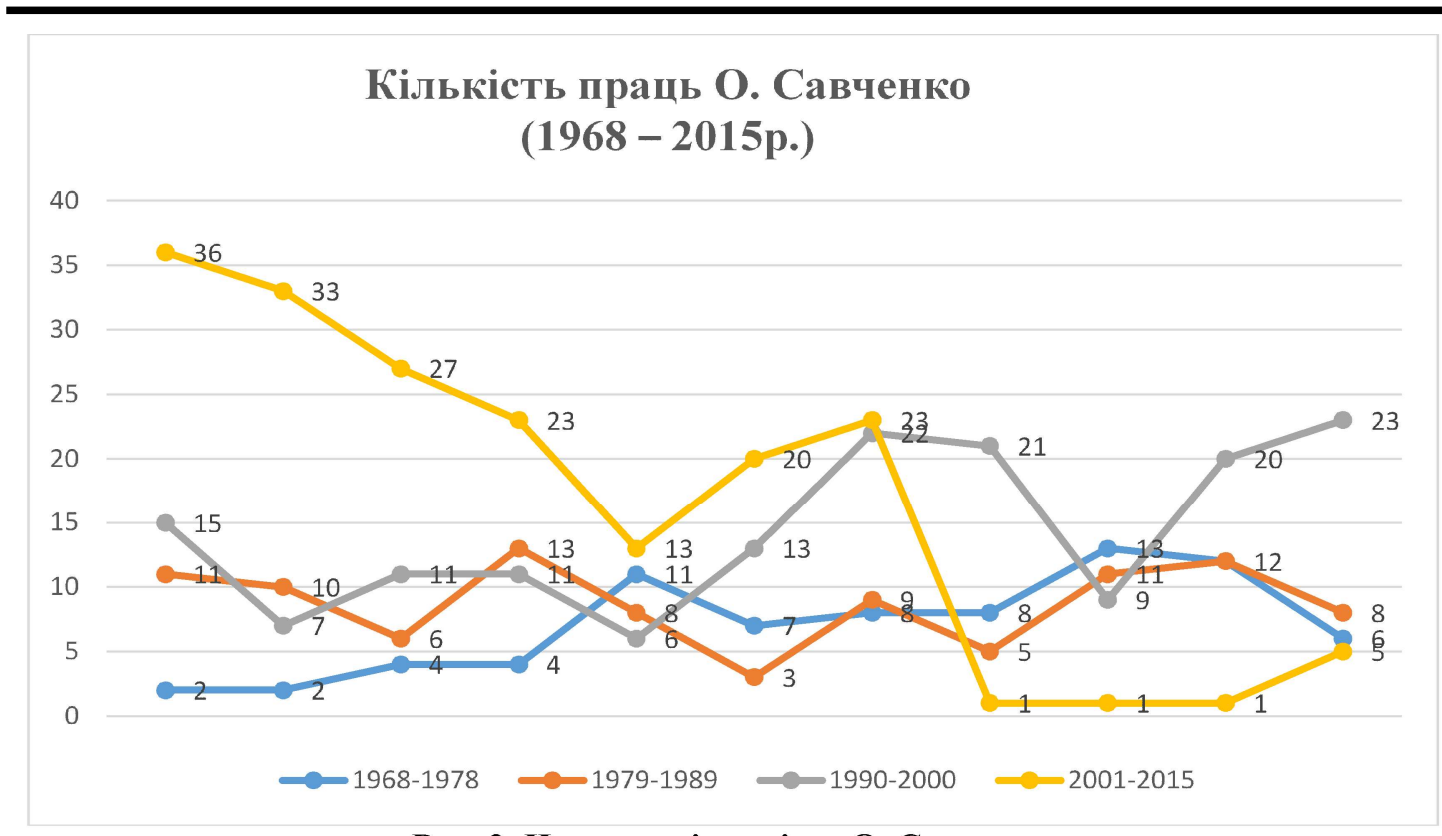

Рис. 2. Наукова діяльність О. Савченко

розвивального змісту (до прикладу, “Барвистий клубочок”, “Розвивай свої здібності”, “Умій вчитися"); посібники для педагога ("Урок у початкових класах”, “Сучасний урок у початкових класах”, “Читання в 4 класі”, “Виховний потенціал початкової освіти”). Намагаючись сприяти розвитку освітньої галузі, О. Савченко не оминула увагою й батьків вихованців, створюючи для них різноманітні книги, порадники, вказівки задля полегшення організації навчання, виховання, розвитку дітей (“Сімейне виховання”, “Молодші школярі”).

Проблеми професійної підготовки майбутніх фахівців неодноразово порушувались О. Савченко. Свідченням цьому є не лише наукові статті про потребу професійного зростання, здійснення неперервної освіти, самовдосконалення, а й низка створених для студентів закладів вищої освіти підручників, як-от: “Дидактика початкової школи”, “Підготовка студентів до роботи з учнями 6річного віку".

Намагаючись сконцентрувати увагу на питаннях початкової освіти, які розглядала відома вчена, ми здійснили порівняльний аналіз її наукових праць, виокремлюючи актуальну для О. Савченко тематику. Наше дослідження показало таке (Рис.1).

Окрім того, наше дослідження засвідчило, що кількість праць, написаних О. Савченко на різних етапах ii життя, відрізняється за своєю чисельністю, демонструючи наукову активність дослідниці (Рис. 2).

Як бачимо з Рис. 2., найбільш активним періодом наукової творчості були 2001-2015 pр. 3
1968 до 1978 рр. вона стала автором 77 робіт, 1979-1989 pp. - 96, з 1990-2000 pp. - 158, 20012015 - 183 робіт. 32008 року О. Савченко здійснювала наукове керівництво 61 дисертаційним дослідженням, що, своєю чергою, уможливлює твердження, що вчена безпосередньо консультувала молодих дослідників з питань розвитку освіти в Україні; ділилася власним досвідом діяльності та створювала можливості розвитку нової генерації науковців у країні. Зрозуміло, ця сфера діяльності позитивно впливала на зростання, з одного боку, мотивації молоді до вивчення передового педагогічного досвіду, наукового доробку, а 3 іншого - сприяла становленню та розвитку науки, педагогічної практики. Загальновідомо, що українська вчена О. Савченко підготувала докторів та кандидатів педагогічних наук, розкриваючи внутрішній потенціал науковців та мотивуючи до подальшого зростання: “Якщо стиснути до афоризму особистісну характеристику нашого вчителя, то можна сказати: талановита, справжня, вимоглива, доброзичлива, духовна. I коли зустрінеш у житті таку Людину - Особистість, то час переростає у щось невимовно значне, що вивищує тебе над самим собою, зумовлює професійну наснагу і відповідальність" - так про Олександру Яківну пишуть їі учні [7, 7]. О. Савченко вважаємо наставником не одного покоління науковців, які й сьогодні втілюють у своїй діяльності кращі ідеї відомого педагога (Н. Бібік, Г. Васьківська, Л. Ващенко, Н. Глузман, Л. Коваль, Я. Кодлюк, О. Локшина, М. Марусинець, Л. Хоружа та інші). У 2018 р. під час інтерв’ю журналу “Директор 


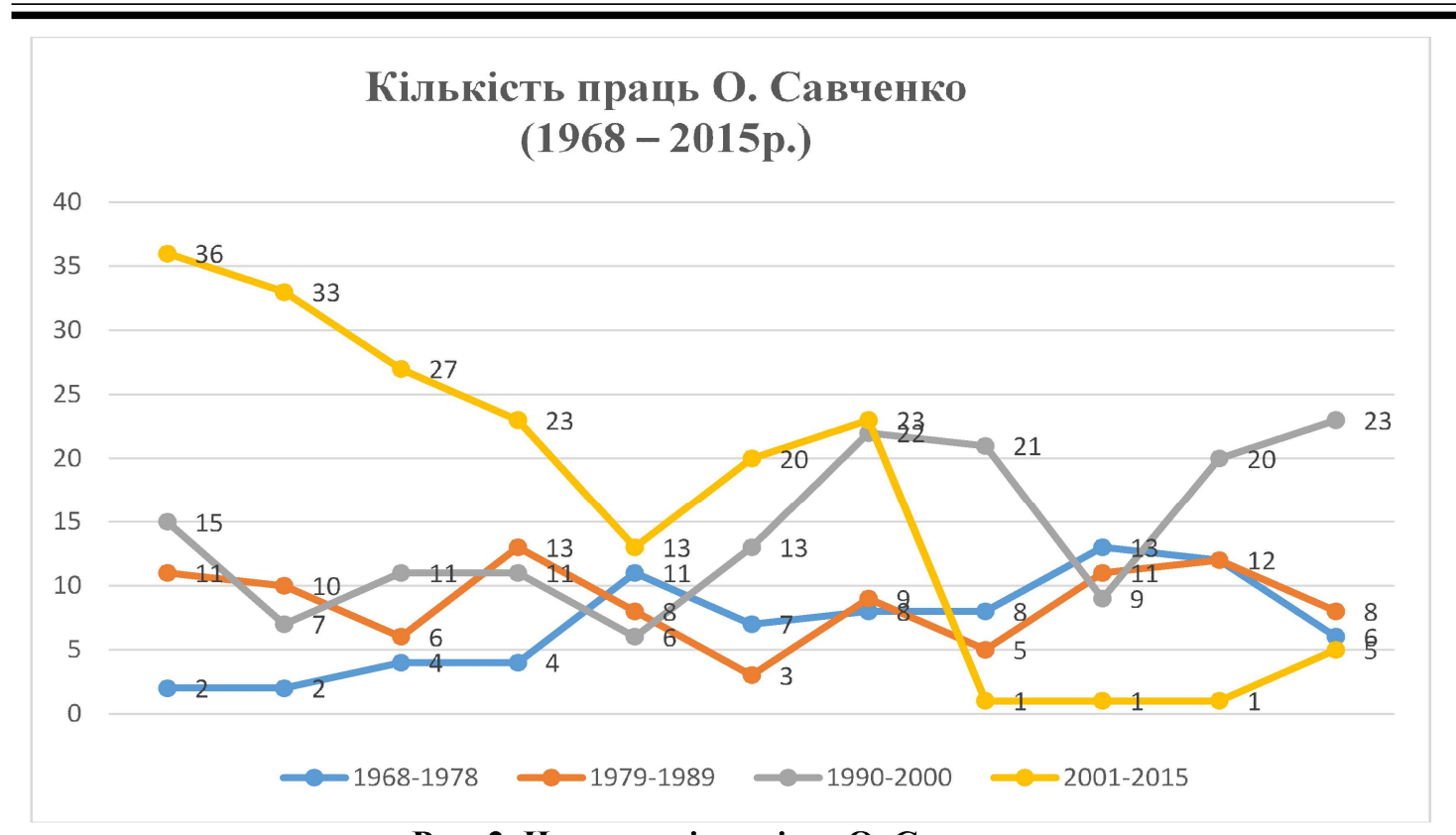

Рис. 2. Наукова діяльність О. Савченко

школи. Шкільний світ" О. Савченко наголосила на тому, що попереду у всіх - велика робота. У такий спосіб відома вчена наголосила, що молодій генерації науковців слід продовжувати змінювати та удосконалювати освіту в Україні. Зокрема основними настановами О. Савченко молодим науковцям, учителям-практикам були:

1. Бути терплячими й оптимістичними щодо себе, а найбільше - до вихованців. Цю істину О. Савченко підкріплює переконанням у тому, що молодий учитель, не маючи практичного досвіду, не володіє інформацією про вихованців, їх можливості та здібності, власні сили реалізації професійних завдань, а тому йому належить виховувати у собі позитивні риси та якості, стрижневими 3-поміж яких є терплячість, такт, тактовність, вихованість, відкритість;

2. Учитель, який має незначний практичний досвід (один-два роки) перебуває у стані професійного становлення. Саме тому, на міркування О. Савченко, молодий фахівець, який прагне стати професіоналом у царині освіти, повинен “бути марафонцем”. На ії думку, це вивчення передового педагогічного досвіду, його упровадження у власній діяльності, пошук своїх способів вирішення питання;

3. Педагог - гуманіст. О. Савченко звертає увагу на молодих учителів щодо потреби вивчення наукового доробку В. Сухомлинського та використання кращих надбань теорії й практики у власній діяльності. Чільне місце у іiі роботах посідають ідеї людинолюбства, самоцінності дитинства, поваги особистості, її прав та свобод, які, своєю чергою, дозволяють успішно здійснювати професійну діяльність;
4. Систематичне самовдосконалення учителя (виховання організованості, терплячості, відповідальності). На думку О. Савченко, саме такий педагог "не загубить суті". Дослідниця наголошує, що учитель повинен бути уважним до кожного школяра, варіювати різні за навантаженням і типом складності завдання, уміти прогнозувати та передбачати ймовірні результати власних та дій учнів. О. Савченко стверджує: “На мою думку, особистісні якості вчителя, його загальна культура важливіші за методичну навченість" [2].

Одне із головних завдань підготовки майбутніх учителів Нової української школи полягає у формуванні їх професійної компетентності, що дає змогу бути готовими до формування всебічно розвиненої особистості здобувача освіти, забезпечення інтегрованості (внутрішньопредметної і міжпредметної) шляхом наближенням змісту освіти до сенситивних періодів навчання, особливостей сприймання нової інформації школярами $[6,122]$. У контексті означеного вважаємо за необхідне виокремити напрацювання О. Савченко, що припадають на 90-ті рр., які присвячено проблемі реформування освітньої галузі у період першого десятиліття незалежності України. Вчена констатує низку прогалин у цій сфері, які спостерігалися у процесі переходу від авторитарної до особистісно орієнтовної освіти, ії перебудові на новий лад, внесенні нових акцентів та встановлення цінностей. Вивчення праць О. Савченко зазначеного періоду допомагає нам виокремити найбільш вагомі з-поміж них, а саме (Табл. 1): 
Наукова діяльність О. Савченко у 1990-ті роки

\begin{tabular}{|c|c|}
\hline Рік написання & Назва публікації \\
\hline 1 & 2 \\
\hline 1996 & “Реформування змісту початкової освіти” \\
\hline 1997 & “Освіта має стати загальнодержавним пріоритетом” \\
\hline 1998 & “Основні напрями реформування шкільної освіти” \\
\hline 1999 & “Зміст шкільної освіти на рубежі століть” \\
\hline 1999 & “Стан і завдання реформування змісту загальної шкільної освіти” \\
\hline 1999 & “Закон про загальну середню освіту - нові умови її стабільного розвитку” \\
\hline
\end{tabular}

Джерело: [власні спостереження автора]

Дані Таблиці 1 свідчать про те, що проблеми розвитку освіти у нашій країні - питання за номером один у діяльності дослідниці. За такого підходу звертаємо увагу на твердження О. Савченко про те, що: "В освіті головні цінності - дитина і педагог, здатний розвивати, захищати, оберігати iiі індивідуальність. А звідси - центрованість на ідеях: людина - не засіб, а мета, тому не дитину треба пристосовувати до системи освіти, а школу до неї” [3].

Перебуваючи у постійному пошуку нових найбільш ефективних шляхів оновлення змісту шкільної освіти, професор О. Савченко акцентує увагу на цінному творчому доробку відомих педагогів минулого, а саме В. Сухомлинського. Аналізуючи його праці, О. Савченко намагається знайти розв'язання низки проблем, а саме:

- формування змісту шкільної освіти та розвивальний ії потенціал;

- покликання початкової школи;

- співвідношення галузей освіти упродовж навчання;

- розкриття можливостей освіти щодо гармонійного розвитку особистості (сприяння зростанню інтелектуальної, мотиваційної, пізнавальної, когнітивної, емоційної сфери);

- професійний розвиток педагога (самоосвіта, самовдосконалення). Так, на думку О. Савченко, учитель повинен знати і розуміти світ дитинства тощо $[4,7]$.

Аналізуючи творчу спадщину відомого педагога В. Сухомлинського, О. Савченко зупиняється на авторському ідеалі справжньої людини, в основі якого - формування особистості на засадах народної педагогіки, прищеплення їй суспільно значущих, загальнокультурних, громадянських цінностей тощо. Дослідниця доводить вагомість внеску В. Сухомлинського у теорії і практиці розвивального навчання, реформування школи; актуалізує гуманізм, людяність, дитиноцентризм у навчально-виховному процесі. Будучи скромною особистістю, О. Савченко не соромиться навчатися в інших, поглиблює свої знання й закликає до цього кожного.

Висновки. Вищеозначене дозволяє стверджувати, що творча спадщина видатного педагога й науковця, О. Савченко є свідченням копіткої й натхненної, самовідданої діяльності задля українського народу, розвитку освіти та процвітання України. Широкий спектр питань, висвітлених у наукових працях О. Савченко, уможливлює розкрити зміст, функції, особливості освітньої галузі та скеровує ïх у відповідному напрямі професійної діяльності та саморозвитку. Багатоаспектність напрямів практичної діяльності вченої водночас підтверджує іiі вагомий внесок, працьовитість, талант, який нам слід продовжувати й примножувати.

\section{ЛІТЕРАТУРА}

1. Березівська Л. Внесок О.Я. Савченко в розвиток історико-педагогічної науки України. Основні напрями наукового пошуку. С. 5. URL: https://1ib.iitta.gov.ua/713261/1/ $\%$ D0\%92\%D0\%BD\%D0\%B $\%$ D 1\%81\%D 0\%BE\%D0\%BA\%20\%D0\%9E.\%20\%D0\%A F. $\% 20 \% \mathrm{D} 0 \% \mathrm{~A} 1 \% \mathrm{D} 0 \% \mathrm{~B} 0 \% \mathrm{D} 0 \% \mathrm{~B} 2 \% \mathrm{D} 1 \% 87 \% \mathrm{D} 0 \%$ B5\%D0\%BD $\%$ D0\%BA\%D0\%BE.pdf

2. Інтерв'ю Олександри Яківни Савченко. URL: http://www.osvitaua.com/2018/08/65957/

3. Савченко О. Я. Дидактика початкової школи: 
Підручник для студентів педагогічних факультетів. Київ: Генеза, 2002. С. 368.

4. Савченко О.Я. Вихователь має знати i розуміти світ дитинства. Початкова школа. 2008. № 4. C. 7 .

5. Савченко О.Я. Досвід реформування української освіти: уроки і подальший поступ. Шлях освіти. 2010. № 3.

6. Степанюк К. Професійна підготовка майбутніх учителів початкової школив контексті пріоритетів концепції НУШ. Молодь і ринок №2 (188), 2021. С.121-125.

7. Топузов О.М. Вступне слово: Олександра Яківна Савченко: особистість, вчений, гордість інституту педагогіки. Український педагогічний журнал. 2017, № 2. С.5 - 7 .

\section{REFERENCES}

1. Berezivska, L. Vnesok O.Ya. Savchenko v rozvytok istoryko-pedahohichnoi nauky Ukrainy [Contribution of O.Y. Savchenko in the development of historical and pedagogical science of Ukraine]. The main directions of scientific research. p. 5 . Available at: https://lib.iitta.gov.ua/713261/1/ \%D0\%92\%D0\%BD\% D0\%BE \%D0\%BA\%20 \%D0\%9E.\%20\%D 0\%AF.\%20\% D0\%A $1 \%$ D0\%B0 $\%$ D0 \%B2\%D1\%87\% BA\%D0 \%BE.pdf [in Ukrainian].

2. Interviu Oleksandry Yakivny Savchenko.
Available at: http://www.osvitaua.com/2018/08/ 65957/ [in Ukrainian].

3. Savchenko O. Ya. (2002). Dydaktyka pochatkovoi shkoly [Didactics of primary school]. Textbook for students of pedagogical faculties. Kyiv, p. 368. [in Ukrainian].

4. Savchenko, O. Ya. (2008). Vykhovatel maie znaty i rozumity svit dytynstva [The educator must know and understand the world of childhood]. Elementary School. No. 4, p. 7. [in Ukrainian].

5. Savchenko, O.Ya. (2010). Experience of reforming Ukrainian education: lessons and further progress [Dosvid reformuvannia ukrainskoi osvity: uroky i podalshyi postup]. The path of education. No 3. [in Ukrainian].

6. Stepanyuk, K. (2021). Profesiina pidhotovka maibutnikh uchyteliv pochatkovoi shkolyv konteksti priorytetiv kontseptsii NUSh [Professional training of the future teachers of primary education withinthe context of priorities of the concept of modern ukrainian school]. "Youth and market". Monthly scientific-pedagogical journal. No.2 (188), pp.121 -125 . [in Ukrainian].

7. Topuzov, O.M. (2017). Introductory word: Oleksandra Yakivna Savchenko: personality, scientist, pride of the institute of pedagogy [Vstupne slovo: Oleksandra Yakivna Savchenko: osobystist, vchenyi, hordist instytutu pedahohiky]. Ukrainian pedagogical journal. No. 2, pp. 5 - 7. [in Ukrainian].

Стаття надійшла до редакції 14.12.2021

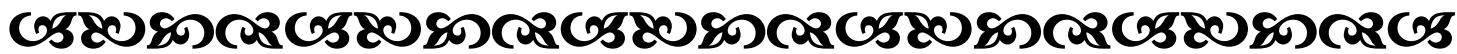

"Ми всі приходимо у ией світ з певними иілями. Dумаю, одна з иілей полягає в тому, щоб запалити фақел $і$ повести за собою людей қрізь темряву”.

Bуni Толдберг

американсьқа акторка

"ТТоріння інтелекту переживають шумну суєту поқолінь $і$ на протязі століть зігрівають світ теплом і світлом".

Альберт Ейнштейн один з найвизначніших бізиків ХХ століття

"ТТим, ким я є, або сподівався коли-небудь бути, я завдячую своєму ангелу мamepi".

Авраам Аінкольн

колишній президент США

\section{ज5808}

